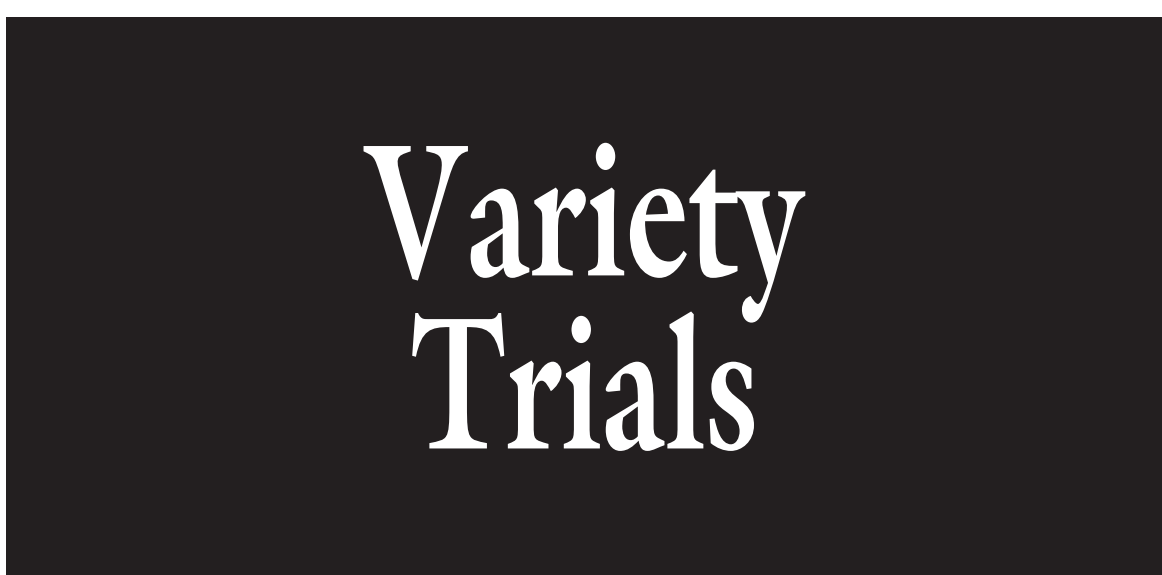

\title{
Growth, Flowering, and Cold Hardiness of Rockrose in Western Oregon
}

\author{
Neil C. Bell ${ }^{1,3}$ and James Altland ${ }^{2}$
}

\begin{abstract}
AdDitional Index words. Cistus, Halimium, drought, landscape, shrubs
\end{abstract}
Summary. Ninety-three species, cultivars, and hybrid selections of rockrose (Cistus spp., Halimium spp., and $\times$ Halimiocistus spp.) were evaluated for growth, flowering, and cold hardiness in a landscape trial in Aurora, OR, from 2004 to 2009. Plants were irrigated to aid establishment when planted in summer 2004, but thereafter were not watered, fertilized, or pruned throughout the trial. Cold damage was recorded following freezing events in Feb. 2006 and Dec. 2008 in which low temperatures were 20 and $17^{\circ} \mathrm{F}$, respectively. Those plants that consistently suffered the most cold damage were Halimium atriplicifolium, Cistus creticus ssp. creticus 'Tania Compton', Cistus $\times$ pauranthus, and Cistus albidus forma albus. Other plants showed cold damage related to poor vigor. The length of the flowering period and foliage quality varied widely among plants in the evaluation. The plants with the longest flowering period were Halimium $\times$ pauanum, Cistus inflatus, Cistus $\times$ pulverulentus 'Sunset', and $\times$ Halimiocistus 'Ingwersenii', all of which flowered for more than $\mathbf{5 5}$ days. Plant form and foliage quality declined drastically for some plants during the evaluation. Those that retained the best foliage quality included Cistus $\times$ obtusifolius, Cistus $\times$ laxus, Cistus salviifolius 'Gold Star', Cistus 'Gordon Cooper', Halimium lasianthum 'Sandling', Halimium 'Susan', and $\times$ Halimiocistus sabucii. Based on ratings of foliage and bloom time, as well as hardiness, several Cistus are recommended as droughttolerant groundcovers, including Cistus $\times$ gardianus and C. $\times$ obtusifolius. Cistus $\times$ laxus, C. inflatus, Cistus 'Gordon Cooper', Cistus 'Ruby Cluster', and Cistus 'Snow Fire' are suggested as tall groundcovers or landscape specimens. Several Halimium are recommended for landscape use, including $H$. lasianthum 'Sandling', Halimium 'Susan', H. ×pauanum, and $\times$ Halimiocistus 'Ingwersenii'.

$\mathrm{R}$ ockroses are genera of evergreen, woody shrubs of the family Cistaceae, native principally to the Mediterranean basin. The 20 species of Cistus and seven species of Halimium have remained as separate genera since the 18th century (Page, 2009). The hybrid of these two genera $(\times$ Halimiocistus $)$ contains three species. Recently, Demoly (2006) has proposed assigning all the Halimium and $\times$ Halimiocistus to Cistus. As the plants in this evaluation were obtained and evaluated under their previous names, those will be retained for the purposes of this evaluation.

The distribution of Cistus ranges from the Canary Islands to the Caucasus
Mountains. Halimium are confined to the western Mediterranean and Greece. The climate in which these plants originated is Mediterranean, with mild, rainy winters and warm to hot, dry summers. Throughout this region, rockroses form an important component of the xeric maquis shrub community. All the species are evergreen shrubs and range in habit from prostrate to sprawling or, in some cases, erect large shrubs. Although evergreen, they are considered drought semideciduous (malacophyllous), possessing the ability to develop different types of leaves in summer and winter, and to drop leaves during prolonged periods of drought (Acosta et al., 1997). As a result, rockroses are well adapted to growing in hot, dry situations, and in relatively poor soils.

Western Oregon is characterized by a climate with a mild, wet winter and a pronounced summer drought and is comparable to the cool humid Mediterranean climate characteristic of southern France (Nahal, 1981). Nevertheless, few rockroses are grown or used extensively in landscapes in western Oregon or Washington. The most commonly grown are Cistus $\times$ bybridus and Cistus $\times$ purpureus, both of which may be used as tall groundcovers or specimen shrubs. The genus has suffered from a reputation of being shortlived and tender. This reputation may partly be a result of the limited selections cultivated, but may also be attributed to plants being grown in landscapes that are watered regularly in summer, a common practice in summer-dry areas such as western Oregon.

Published studies on hardiness of rockroses are rare and tend to be anecdotal in nature. Johnson (1947) commented briefly on the relative hardiness of some common Cistus in the United Kingdom after cold weather in Feb. 1947. Mulligan (1953) evaluated $\approx 18$ species and cultivars of Cistus and $\times$ Halimiocistus in Seattle, WA, from 1949 to 1953 and found significant variations in

\begin{tabular}{llll}
\hline $\begin{array}{l}\text { Units } \\
\text { To convert U.S. to SI, } \\
\text { multiply by }\end{array}$ & U.S. unit & SI unit & $\begin{array}{l}\text { To convert SI to U.S., } \\
\text { multiply by }\end{array}$ \\
\hline 0.4047 & acre(s) & ha & 2.4711 \\
0.3048 & $\mathrm{ft}$ & $\mathrm{m}$ & 3.2808 \\
2.54 & inch $(\mathrm{es})$ & $\mathrm{cm}$ & 0.3937 \\
28.3495 & $\mathrm{OZ}$ & $\mathrm{g}$ & 0.0353 \\
$\left({ }^{\circ} \mathrm{F}-32\right) \div 1.8$ & ${ }^{\circ} \mathrm{F}$ & ${ }^{\circ} \mathrm{C}$ & $\left(1.8 \times{ }^{\circ} \mathrm{C}\right)+32$
\end{tabular}


hardiness and ornamental qualities. Mundie (2001) evaluated Cistus in northern England from 1997 to 2001. However, most research on response of rockroses to winter conditions has focused on physiological responses of the plants to cool winter temperatures, not necessarily their specific cold hardiness. Various studies have demonstrated changes in chlorophyll content (Nunez-Olivera et al., 1994), pigments and antioxidants (Garcia-Plazaola et al., 2000), and photosynthesis (Oliveira and Penuelas, 2004). These studies do not typically relate these changes to hardiness, although in a study of physiological responses of eight Mediterranean shrubs to winter stress, Varone and Gratani (2007) found Cistus incanus (synonym $=$ Cistus creticus) to be one of the least cold hardy and suggested that in addition to summer drought, winter temperatures might represent an additional limitation to Mediterranean species productivity. The objective of our study was to determine the growth and relative hardiness of rockrose species and cultivars under western Oregon conditions.

\section{Materials and methods}

Species, selections, and cultivars of rockroses were from two main sources. A total of 98 species and cultivars was obtained from nursery sources in California or from the United Kingdom. Fifteen of these were obtained as stock plants from nurseries in California in Sept. 2003. These plants were grown on through early October, at which time 4-inch-long tip cuttings were taken. Unrooted tip

The authors appreciate and would like to acknowledge financial support from the Agricultural Research Foundation of Oregon State University (Corvallis, OR), as well as the donation of plants by Anderson Valley Nursery (Boonville, CA), Digging Dog Nursery (Albion, CA), and Suncrest Nursery (Watsonville, CA).

We would like to particularly thank Mr. Robert G. Page (Leeds, UK) for his contribution of the majority of the cultivars in the evaluation, as well as ongoing assistance with the preparation of the manuscript. Thanks are also due to OSU Marion County Master Gardeners for assistance with plot maintenance and data collection.

${ }^{1}$ Oregon State University Extension Service, Marion County, 3180 Center Street NE, No. 1361, Salem, OR 97301

${ }^{2}$ U.S. Department of Agriculture-Agricultural Research Service Application Technology Research, Unit 208, Agricultural Engineering Building, 1680 Madison Avenue, Wooster, OH 44691

${ }^{3}$ Corresponding author. E-mail: neil.bell@oregonstate. edu. cuttings of the other 83 plants were obtained from the National Collection of Cistus and Halimium held by R. Page in Leeds, UK, in Oct. 2003. These cuttings, and those from the stock plants, were stuck in early Oct. 2003 in 4 perlite: 1 peatmoss $(\mathrm{v} / \mathrm{v})$ mix at the Oregon State University (OSU) North Willamette Research and Extension Center (NWREC) in Aurora. Cuttings were rooted in a polyethylene-covered hoop house, using bottom heat, but no mist. Five cultivars failed to root in sufficient number and were not included in the evaluation. Rooted cuttings were potted into 6inch square nursery pots in Mar. 2004 and were top-dressed with $10 \mathrm{~g}$ of $18 \mathrm{~N}-3.5 \mathrm{P}-6.6 \mathrm{~K}$ controlled-release fertilizer (Apex ${ }^{\circledR}$ Evergreen; Pursell Technologies, Sylacauga, AL). Plants were maintained until planting in the evaluation site on 22 June.

The evaluation site was a southfacing slope at NWREC (lat. $45^{\circ} 57^{\prime} \mathrm{N}$, long. $122^{\circ} 45^{\prime} \mathrm{W}, 155 \mathrm{ft}$ elevation). The evaluation site was $\approx 0.5$ acre. The soil series was a Willamette silt loam. Before planting, the site was subsoiled to a depth of $\mathrm{l} \mathrm{ft}$, and was then disked to break up and level the soil. The trial was divided into 12 rows $185 \mathrm{ft}$ long, spaced $10 \mathrm{ft}$ apart, orientated north to south. Individual plants were randomly assigned to rows and planted at an in-row spacing of $5 \mathrm{ft}$. Plants were planted in a completely randomized design with four replicates.

After planting, plants were watered in by hand, and then received periodic overhead water sufficient to keep the top 6 inches of soil moist through the end of Aug. 2004. Plants received no supplemental irrigation after this time. No fertilizer was applied at planting or thereafter for the duration of the trial. Plants were not pruned. Because irrigation was not provided in summer, the plot remained mostly weed-free, and weed management involved occasional hand weeding. The exception to this was a one-time spot application of glyphosate (Roundup; Monsanto, St. Louis) to control a crabgrass (Digitaria spp.) infestation in Summer 2004 caused by the irrigation during establishment.

Data collected included plant height and width, flowering season, cold hardiness evaluation, and plant form and foliage quality. Plant height (ground level to tallest shoot) and width (mean of the widest diameter and width perpendicular to the widest diameter) were measured at establishment and again each year in fall. Flowering was evaluated by rating bloom on the plants weekly on a 0 to 5 scale. A rating of " 0 " was given to plants with no open flowers; "l" meant at least one open to less than 20\% bloom; "2" meant $20 \%$ to less than $40 \%$ bloom; " 3 " meant $40 \%$ to less than $60 \%$ bloom; " 4 " meant $60 \%$ to less than $80 \%$ bloom; " 5 " meant $80 \%$ bloom or greater and was reserved for shrubs whose foliage was obscured by bloom.

Cold hardiness evaluations were done in early spring after mild weather allowed for full symptom development from any prior cold injury. Data were collected only in Apr. 2006 and in Apr. 2009 , as there was no apparent damage following Winter 2004-05, 200607, and 2007-08. Cold damage was rated on a 0 to 5 scale, adapted from Lonard and Judd (1991) with "0" indicating no damage; "l" meant minor leaf damage (browning); "2" meant leaf and stem damage restricted to the exterior $30 \%$ of the plant; " 3 " meant leaf and stem damage to the exterior $60 \%$ of the plant; " 4 " meant the plant was killed to the crown with resprouting; and " 5 " indicated the plant was dead. Regional weather data were obtained from the U.S. Bureau of Reclamation Agrimet weather station at NWREC, located $\approx 400 \mathrm{ft}$ from the trial site (U.S. Bureau of Reclamation, 2009).

Foliage quality and overall plant form were rated on a 1 to 5 scale, with "l" meaning a plant with less than $20 \%$ of a full canopy, indicating a sparsely foliated plant with poor form and dieback; " 2 " meant $20 \%$ to $40 \%$ canopy, with foliage thinly distributed over the canopy and some dieback; " 3 " meant $40 \%$ to $60 \%$ canopy, with foliage well distributed on the plant and minimal dieback; " 4 " meant $60 \%$ to $80 \%$ canopy, a well-shaped plant with a dense canopy and minor foliage discoloration or dieback; "5" meant greater than $80 \%$ canopy, essentially a flawless canopy with dense foliage.

Growth, cold damage, and foliage data were summarized by calculating the mean and standard deviation for each accession. Flowering charts were generated in Excel (Microsoft, Redmond, WA) as floating bar charts, indicating the dates on which average flower ratings exceeded the value 2 . 


\section{Results and discussion}

A total of 372 rockroses were planted and these grew and filled in the rows by 2007. There were some significant plant losses over the course of the trial affecting some cultivars in particular. All plants of $C$. 'Enigma' died shortly after planting, a fact we attributed to the poor rooting and consequent small size of the plants at planting. Other than the loss of all plants of this cultivar, other losses occurred sporadically throughout the evaluation from undetermined causes. Among the other Cistus, three 'Silver Ghost' as well as two each of Cistus $\times$ pauranthus, Cistus albidus var. albus, Cistus Xargenteus 'Silver Pink', and Cistus $\times$ dansereaui 'Jenkyn Place' were lost, as well as individual plants of Cistus beterophyllus, Cistus ×ralletii, Cistus Xaguilarii, Cistus monspeliensis, C. $\times$ dansereaui 'Decumbens', Cistus 'Victor Reiter', and Cistus Xheterocalyx 'Chelsea Bonnet'. Among the Halimium, two Halimium atriplicifolium and one each of Halimium xpauanum and Halimium 'Susan' died over the course of the evaluation.

Although aphids (Aphididae) are known to be a pest of Cistus, no serious infestations were observed. The only noticeable disease problem was sooty mold (Capnodiales), which was observed on the foliage of some Cistus cultivars in spring, being especially noticeable on the previous season leaves as the bright green new foliage was emerging. The sooty mold did not appear to be growing on honeydew caused by an aphid infestation; instead, it was apparently using the labdanum that certain plants produce in abundance. The affected plants were Cistus $\times$ ledon, C. ×purpureus, Cistus ladanifer var. sulcatus forma bicolor, C. ladanifer cultivars (including Bashful and Blanche), Cistus xcyprius 'Troubadour', and Cistus $\times$ stenophyllus. Despite this, most of the affected plants continued to grow and flower well and this could be regarded as more of an aesthetic problem. A search of the literature did not reveal any prior research linking labdanum with sooty mold.

Plant growth. By Fall 2006 , many plants had filled their allocated space and some were beginning to grow into one another (Tables 1-4). There was a significant effect $(P<$ 0.0001 ) of cultivar on height and width. The results show that rockroses have a wide range of vigor and growth habit and can be divided into three broad groups based on growth habit: 1) upright shrubs with similar height and width that exceeds $100 \mathrm{~cm}$; 2) mounding shrubs that are wide spreading with heights between 80 and $130 \mathrm{~cm}$ and widths about twice that; and 3 ) low spreading groundcovers with heights not exceeding $80 \mathrm{~cm}$ and twice that in width. In general, white, blotchedflowered Cistus tend to be the most vigorous, followed by white-flowered, then pink-flowered plants. Because of the predominance of low-growing plants, the yellow-flowered Halimium tend to be the most diminutive overall.

Of the upright shrubs, the tallest in the evaluation was Cistus $\times$ verguinii 'Salabert', which formed a very open $\mathrm{V}$-shaped shrub and produced many ascending, sparsely foliated stems ( $\mathrm{Ta}-$ ble 1). Somewhat shorter than this, but forming a much denser shrub, was C. Xaguilarii (often erroneously sold in North America as Cistus 'Blanche'), which has thick, wavy-edged leaves and from an ornamental standpoint is far superior to C. xperguinii (Table 2). Slightly smaller than this were 'Bennett's White', 'Blanche', and 'Troubadour', all of which form wellshaped shrubs, although as mentioned previously, sooty mold did mar the foliage of the latter two cultivars. The tallest of the pink-flowered Cistus, 'Victor Reiter', was only slightly smaller than these three (Table 3). The tallest of the Halimium was H. xpananum by a considerable margin, followed by Halimium $\times$ santae and Halimium balimifolium (Table 4). The majority of Halimium are low-growing plants.

Among the mounding, spreading shrubs, the most vigorous were Cistus Xlaxus 'Snow White', Cistus ×oblongifolius, Cistus 'Snow Fire', Cistus'Jessamy Beauty', Cistus 'Gordon Cooper', and Cistus 'Ann Baker', which vary somewhat in height but which typically form broad, dense domes (Tables 1 and 2). These cultivars would all be effective as tall groundcovers for

Table 1. Plant size, foliage rating, and cold injury rating for blotched, white-flowered rockrose evaluated in Aurora, OR, from 2004-09. Mean of four replications.

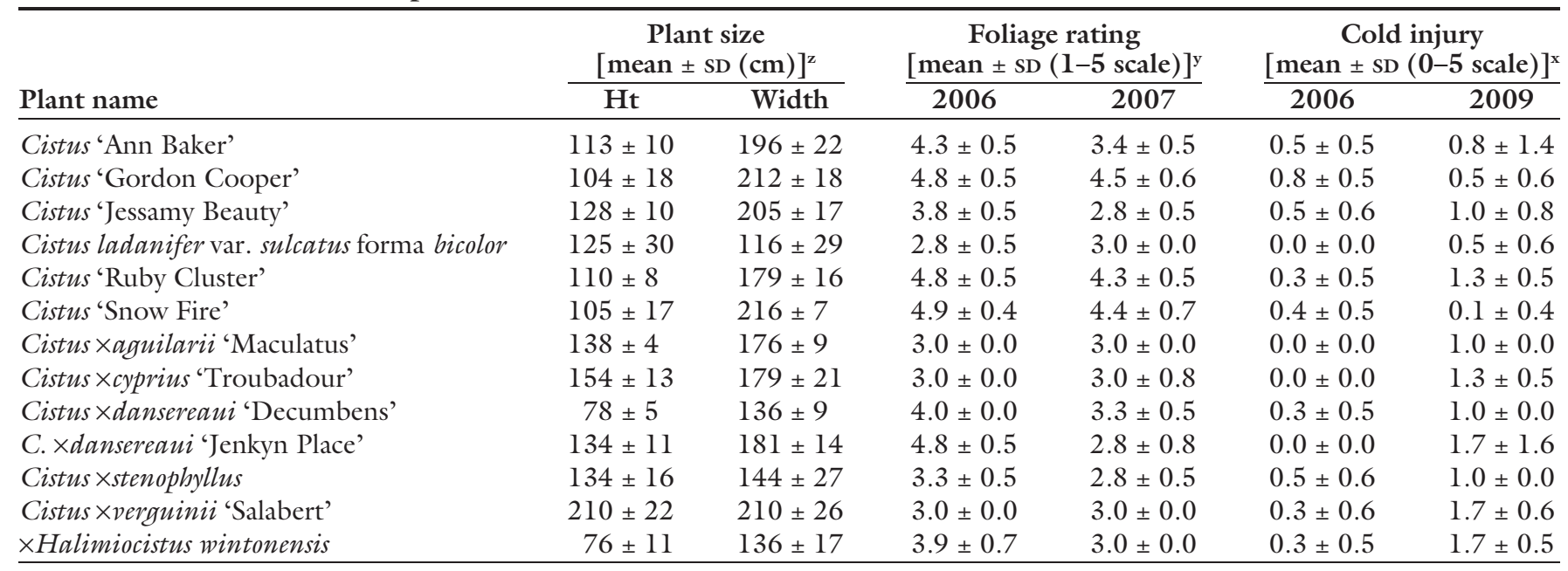

${ }^{2}$ Plant size measured in Sept. 2006 after 2 years of growth; $1 \mathrm{~cm}=0.3937$ inch.

${ }^{y_{1}}=$ sparse foliage and dieback, $5=$ full canopy with no irregularities.

${ }^{\mathrm{x}} 0=$ no injury, $5=$ complete plant death. 
Table 2. Plant size, foliage rating, and cold injury rating for white-flowered rockrose evaluated in Aurora, OR, from 2004-09. Mean of four replications.

\begin{tabular}{|c|c|c|c|c|c|c|}
\hline \multirow[b]{2}{*}{ Plant name } & \multicolumn{2}{|c|}{$\begin{array}{c}\text { Plant size } \\
{[\text { mean } \pm \mathrm{SD}(\mathrm{cm})]^{\mathrm{z}}}\end{array}$} & \multicolumn{2}{|c|}{ 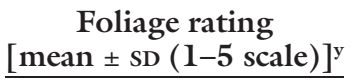 } & \multicolumn{2}{|c|}{$\begin{array}{c}\text { Cold injury } \\
{[\text { mean } \pm \mathrm{SD}(0-5 \text { scale })]^{\mathrm{x}}}\end{array}$} \\
\hline & Ht & Width & 2006 & 2007 & 2006 & 2009 \\
\hline Cistus albidus forma albus & $83 \pm 18$ & $106 \pm 27$ & $3.0 \pm 0.0$ & $2.5 \pm 0.7$ & $2.0 \pm 0.0$ & $2.0 \pm 1.4$ \\
\hline Cistus creticus ssp. creticus 'Tania Compton' & $74 \pm 8$ & $101 \pm 8$ & $3.5 \pm 0.6$ & $3.0 \pm 0.0$ & $2.3 \pm 0.5$ & $2.8 \pm 0.5$ \\
\hline Cistus inflatus & $73 \pm 10$ & $141 \pm 21$ & $4.8 \pm 0.5$ & $4.0 \pm 0.0$ & $1.0 \pm 0.0$ & $1.0 \pm 0.0$ \\
\hline Cistus ladanifer 'Bashful' & $98 \pm 10$ & $134 \pm 9$ & $4.0 \pm 0.0$ & $3.8 \pm 0.5$ & $0.0 \pm 0.0$ & $1.0 \pm 0.0$ \\
\hline Cistus libanotis 'Major' & $109 \pm 10$ & $135 \pm 22$ & $3.3 \pm 0.5$ & $2.5 \pm 0.6$ & $0.0 \pm 0.0$ & $0.3 \pm 0.5$ \\
\hline Cistus monspeliensis & $111 \pm 13$ & $143 \pm 19$ & $3.5 \pm 0.8$ & $2.6 \pm 0.7$ & $1.3 \pm 1.0$ & $0.9 \pm 0.7$ \\
\hline C. monspeliensis 'Vicar's Mead' & $116 \pm 11$ & $132 \pm 28$ & $3.3 \pm 0.5$ & $3.3 \pm 0.5$ & $1.0 \pm 0.8$ & $1.0 \pm 0.0$ \\
\hline Cistus populifolius ssp. Major & $101 \pm 10$ & $151 \pm 23$ & $4.5 \pm 0.6$ & $3.8 \pm 0.5$ & $0.3 \pm 0.5$ & $0.3 \pm 0.5$ \\
\hline Cistus salviifolius 'Gold Star' & $106 \pm 27$ & $186 \pm 11$ & $3.8 \pm 0.5$ & $4.8 \pm 0.5$ & $1.0 \pm 0.0$ & $1.0 \pm 0.0$ \\
\hline C. salviifolius 'Prostratus' & $45 \pm 12$ & $128 \pm 22$ & $4.8 \pm 0.5$ & $3.5 \pm 0.6$ & $1.3 \pm 1.0$ & $1.3 \pm 1.0$ \\
\hline Cistus $\times$ canescens 'Albus' & $103 \pm 6$ & $123 \pm 12$ & $3.7 \pm 1.1$ & $3.3 \pm 0.6$ & $0.0 \pm 0.0$ & $0.7 \pm 1.1$ \\
\hline Cistus $\times$ cyprius var. ellipticus 'Elma' & $130 \pm 8$ & $169 \pm 13$ & $3.0 \pm 0.0$ & $2.8 \pm 0.5$ & $0.3 \pm 0.5$ & $0.3 \pm 0.5$ \\
\hline Cistus $\times$ dansereaui 'Portmeirion' & $104 \pm 7$ & $153 \pm 10$ & $4.3 \pm 0.5$ & $3.3 \pm 0.5$ & $0.0 \pm 0.0$ & $0.3 \pm 0.5$ \\
\hline Cistus $\times$ dubius (costei group) & $90 \pm 4$ & $161 \pm 5$ & $4.5 \pm 0.6$ & $3.0 \pm 0.0$ & $0.3 \pm 0.5$ & $0.8 \pm 0.5$ \\
\hline Cistus $\times$ florentinus 'Fontfroide' & $131 \pm 13$ & $158 \pm 9$ & $4.3 \pm 1.0$ & $3.3 \pm 1.0$ & $1.0 \pm 0.0$ & $0.5 \pm 0.5$ \\
\hline C. $\times$ florentinus 'Tramontane' & $63 \pm 16$ & $156 \pm 20$ & $5.0 \pm 0.0$ & $3.8 \pm 0.5$ & $0.8 \pm 0.5$ & $0.0 \pm 0.0$ \\
\hline Cistus $\times$ heterocalyx 'Chelsea Bonnet' & $109 \pm 23$ & $162 \pm 31$ & $3.1 \pm 0.6$ & $2.1 \pm 0.7$ & $1.1 \pm 0.6$ & $1.6 \pm 1.1$ \\
\hline Cistus $\times$ bybridus & $99 \pm 14$ & $179 \pm 9$ & $3.5 \pm 0.6$ & $3.0 \pm 0.0$ & $1.0 \pm 0.0$ & $0.3 \pm 0.5$ \\
\hline Cistus $\times$ laxus & $88 \pm 5$ & $189 \pm 44$ & $5.0 \pm 0.0$ & $5.0 \pm 0.0$ & $0.5 \pm 0.6$ & $0.3 \pm 0.5$ \\
\hline C. $\times$ laxus 'Snow White' & $124 \pm 3$ & $228 \pm 21$ & $5.0 \pm 0.0$ & $4.3 \pm 1.0$ & $0.0 \pm 0.0$ & $0.8 \pm 0.5$ \\
\hline Cistus $\times$ ledon & $91 \pm 9$ & $126 \pm 15$ & $4.3 \pm 0.5$ & $3.3 \pm 0.5$ & $0.0 \pm 0.0$ & $0.5 \pm 0.6$ \\
\hline$\times$ Halimiocistus sabucii & $29 \pm 10$ & $127 \pm 24$ & $4.4 \pm 0.5$ & $4.1 \pm 0.6$ & $0.0 \pm 0.0$ & $0.1 \pm 0.4$ \\
\hline
\end{tabular}

${ }^{2}$ Plant size measured in Sept. 2006 after 2 years of growth; $1 \mathrm{~cm}=0.3937$ inch.

${ }^{y} \mathrm{l}=$ sparse foliage and dieback, 5 = full canopy with no irregularities.

${ }^{\mathrm{x}} 0=$ no injury, $5=$ complete plant death.

large areas. The most vigorous pinkflowered selection of this group was C. ×purpureus. Among Halimium, the largest plants were Halimium lasianthum 'Hannay Silver', and Halimium 'Sarah'. The former is the most vigorous cultivar of $H$. lasianthum.

The lower-growing groundcovers in the trial generally form dense mats of foliage between 50 and $80 \mathrm{~cm}$ tall, with widths approaching three times their height. Many of these would make good small- to medium-scale groundcovers for dry areas. The tallest is 'Sunset', which is a fairly common cultivar. Somewhat lower-growing than this are Cistus 'Grayswood Pink', Cistus $\times$ florentinus
'Tramontane' Cistus $\times$ gardianus, and H. lasianthum 'Sandling'. The other $H$. lasianthum cultivars in the evaluation are somewhat lower-growing than these, although all of the aforementioned cultivars form dense, wide-spreading groundcovers. The lowest-growing plant in the entire evaluation was $\times$ Halimiocistus sabucii, which was less than $30 \mathrm{~cm}$ tall after 3 years (Table 2).

Cold HARdiness. Plants were rated for cold damage in Apr. 2006 and Apr. 2009 (Tables 1-4). The lowest minimum winter temperatures from 2004-09 occurred in Dec. 2005 and Feb. 2006, and in Dec. 2008. The low temperatures on Dec. 15 and
16,2005 were 20 and $19^{\circ} \mathrm{F}$, respectively. A relatively late freeze occurred on $20 \mathrm{Feb}$. 2006, when the temperature dropped to $20^{\circ} \mathrm{F}$. The coldest temperatures over the duration of the evaluation occurred on $16 \mathrm{Dec}$. and 17 Dec. 2008, when the minimum temperatures were $17^{\circ} \mathrm{F}$ and $19^{\circ} \mathrm{F}$, respectively.

The same cultivars tended to show significant damage when evaluated in spring following these events. These include C. creticus' ${ }^{\text {'Tania Comp- }}$ ton', C. ×pauranthus, C. albidus forma albus, and $H$. atriplicifolium. 'Tania Compton' was a selection made at relatively low elevation near Meskla, Crete, and has a reputation as being 
Table 3. Plant size, foliage rating, and cold injury rating for pink-flowered rockrose evaluated in Aurora, OR, from $2004-09$. Mean of four replications.

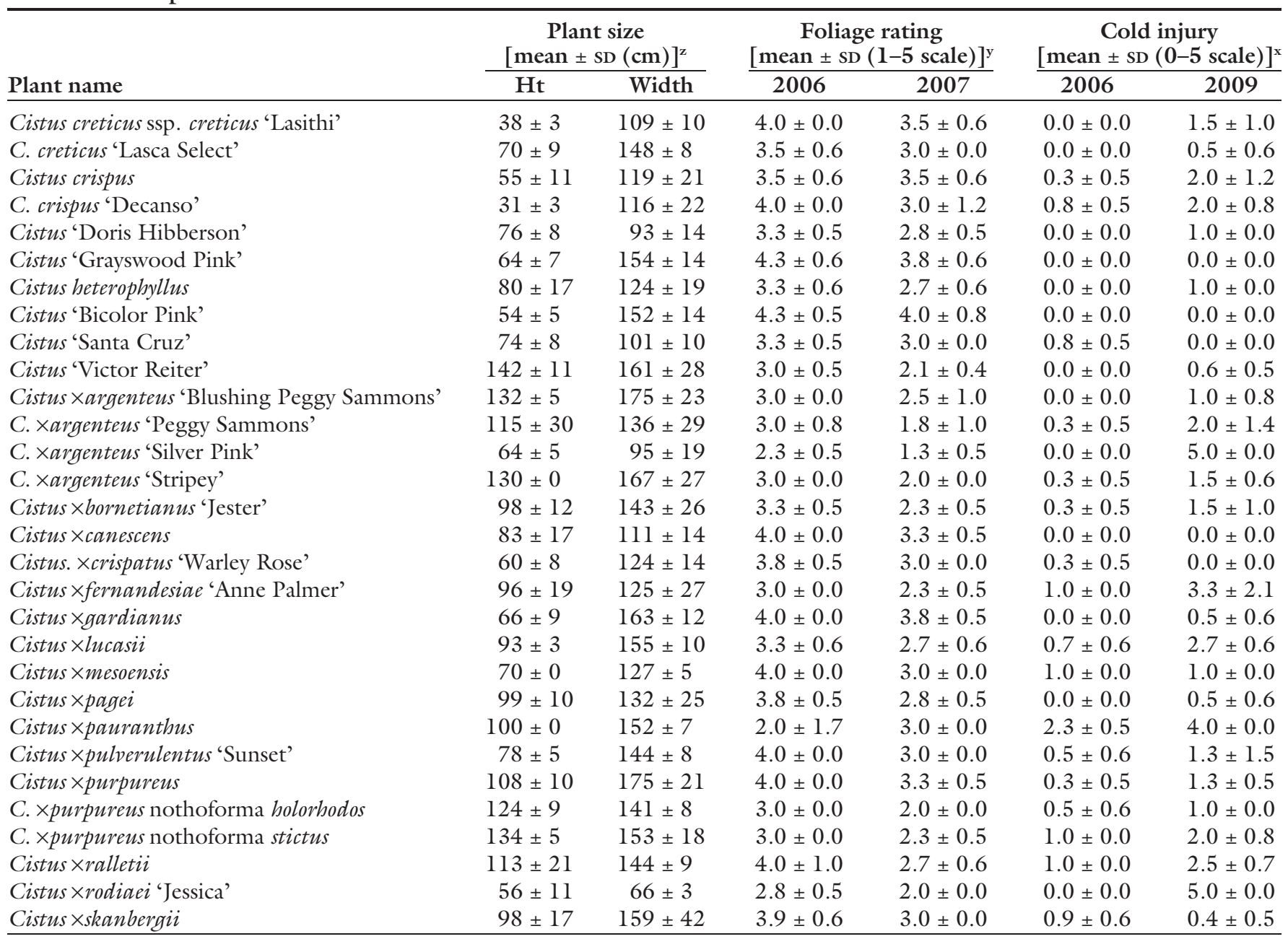

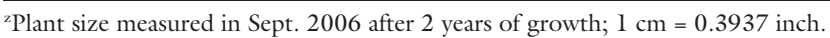

${ }^{\mathrm{y}} \mathrm{l}=$ sparse foliage and dieback, $5=$ full canopy with no irregularities.

${ }^{\mathrm{x}} 0=$ no injury, $5=$ complete plant death.

less hardy. In contrast, 'Lasithi' is another cultivar of $C$. creticus collected in Crete, but on the Lasithi Plateau, which is considerably higher in elevation and may account for its greater hardiness (Tables 2 and 3). C. $\times$ pauranthus was originally selected in the Akamas, Cyprus, which is within a few miles of the Mediterranean and less than $500 \mathrm{ft}$ in elevation and so originated in one of the mildest climates in the region. C. albidus forma albus is a white-flowered variant of $C$. albidus, which is reputed to be one of the shorter-lived species of the genus. Its short-lived reputation may be partly due to its susceptibility to cold injury. Several other cultivars, such as Silver Ghost, Silver Pink, Anne Palmer, Jessica, and C. ×purpureus forma stictus, developed generally poor form and reduced as the evaluation progressed and may have predisposed them to cold injury in 2009 (Table 3). H. atriplicifolium also has a reputation for tenderness and displayed poor foliage and vigor as well (Table 4 ).

Other species or hybrids that exhibited injury, particularly in 2009, included Cistus xlucasii and $C$. $\times$ ralletii. Both of these hybrids have tender Canary Island species in their parentage. Of the remaining plants, most exhibited good hardiness during both cold events. The industry standards, C. $\times$ bybridus and C. $\times$ purpureus, showed relatively minor foliar damage in 2006 and 2009.

Plant Form. Evaluations of foliage quality and plant form were undertaken in response to variations in plant quality that emerged as the trial progressed. Some cultivars that were showy in bloom would become sparse and exhibit dieback by the end of the summer. Leaf drop is a normal response to summer drought in malacophyllous shrubs like rockroses, and the degree of defoliation in response to drought stress varies within Cistaceae (Zunzunegui et al., 2002, 2005). The appearance of some Cistus with bare stems and leaves remaining primarily at the shoot tips is typical of their strategy for survival in the wild, even if this detracts from their ornamental appeal (Acosta et al., 1997). The loss of leaf area to drought stress in summer has been shown to be as high as $61 \%$, with the remaining leaves subject to photoinhibition damage (Werner et al., 1999). Some Cistus, such as $C$. albidus, have been shown to lose not only leaves, but stem and root tissues as well (Sanchez-Blanco et al., 2002). These responses may allow the plant to persist from one year to the next, but render them poor specimens in the landscape. 
Table 4. Plant size, foliage rating, and cold injury rating for yellow-flowered rockrose grown in Aurora, OR, from $2004-09$. Mean of four replications.

\begin{tabular}{|c|c|c|c|c|c|c|}
\hline \multirow[b]{2}{*}{ Plant name } & \multicolumn{2}{|c|}{$\begin{array}{c}\text { Plant size } \\
{[\mathrm{mean} \pm \mathrm{SD}(\mathrm{cm})]^{\mathrm{z}}}\end{array}$} & \multicolumn{2}{|c|}{$\begin{array}{c}\text { Foliage rating } \\
{[\text { mean } \pm \text { SD }(1-5 \text { scale })]^{\mathrm{y}}}\end{array}$} & \multicolumn{2}{|c|}{$\begin{array}{c}\text { Cold injury } \\
{[\text { mean } \pm \text { SD }(0-5 \text { scale })]^{\mathrm{x}}}\end{array}$} \\
\hline & $\mathrm{Ht}$ & Width & 2006 & 2007 & 2006 & 2009 \\
\hline Halimium atriplicifolium & $64 \pm 14$ & $70 \pm 16$ & $2.1 \pm 0.6$ & $1.9 \pm 0.4$ & $1.5 \pm 0.8$ & $2.1 \pm 0.6$ \\
\hline Halimium calycinum & $46 \pm 5$ & $106 \pm 11$ & $4.3 \pm 0.5$ & $3.5 \pm 0.6$ & $0.5 \pm 1.0$ & $0.0 \pm 0.0$ \\
\hline H. calycinum (CA clone) & $66 \pm 13$ & $138 \pm 28$ & $3.5 \pm 0.6$ & $2.8 \pm 0.5$ & $0.3 \pm 0.5$ & $2.3 \pm 1.9$ \\
\hline \multicolumn{7}{|l|}{ Halimium halimifolium } \\
\hline H. lasianthum 'Concolor' & $60 \pm 14$ & $103 \pm 4$ & $4.0 \pm 0.0$ & $3.5 \pm 0.7$ & $0.0 \pm 0.0$ & $0.0 \pm 0.0$ \\
\hline H. lasianthum 'Formosum' & $50 \pm 10$ & $154 \pm 18$ & $4.0 \pm 0.8$ & $3.5 \pm 0.6$ & $0.0 \pm 0.0$ & $0.0 \pm 0.0$ \\
\hline H. lasianthum 'Hannay Silver' & $126 \pm 9$ & $158 \pm 18$ & $4.0 \pm 0.8$ & $3.3 \pm 0.5$ & $0.0 \pm 0.0$ & $0.5 \pm 0.6$ \\
\hline H. lasianthum 'Sandling' & $66 \pm 8$ & $151 \pm 12$ & $4.5 \pm 0.6$ & $4.0 \pm 0.0$ & $0.0 \pm 0.0$ & $0.3 \pm 0.5$ \\
\hline H. lasianthum ssp. alyssoides 'Farrall' & $58 \pm 10$ & $110 \pm 17$ & $3.3 \pm 0.5$ & $3.3 \pm 0.5$ & $0.0 \pm 0.0$ & $0.0 \pm 0.0$ \\
\hline Halimium $\times$ santae & $133 \pm 5$ & $167 \pm 27$ & $3.3 \pm 0.5$ & $2.3 \pm 1.0$ & $0.0 \pm 0.0$ & $2.0 \pm 1.4$ \\
\hline
\end{tabular}

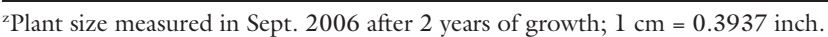

${ }^{y} 1=$ sparse foliage and dieback, $5=$ full canopy with no irregularities.

${ }^{\mathrm{x}} 0=$ no injury, $5=$ complete plant death.

Foliage and form generally declined from 2006 to 2007 (Tables 14 ), but this may be partly the result of the cold injury suffered in Feb. 2006. Those plants that received high ratings generally continued to look good through the end of the evaluation in 2009. The best plants overall were Cistus salviifolius 'Gold Star', C. $\times$ laxus, and Cistus $\times o b t u s i f o l i u s$, all of which exhibited near-flawless foliage, even at the end of the summer drought in 2007 (Table 2). Rated only slightly lower than these were Cistus 'Gordon Cooper' and Cistus 'Snow Fire', both of which have white flowers with blotched petals (Table 1). In general, pink-flowered rockroses seem to display lower foliage quality than white or white-blotched rockroses. Of the former, those with the highest ratings were Cistus 'Grayswood Pink', 'Bicolor Pink', and C. Xgardianus, all of which form dense, low-growing mats of foliage and which make excellent groundcovers (Table 3 ). Among the Halimium, most of the selections of $H$. lasianthum stood out as having good foliage quality, particularly 'Sandling' (Table 4). Others that retained good appearance included 'Susan' and H. xpauanum, which as a large, upright-growing plant, was far superior in quality to $H$. $\times$ santae.

Flowering. As might be expected with such a large number of

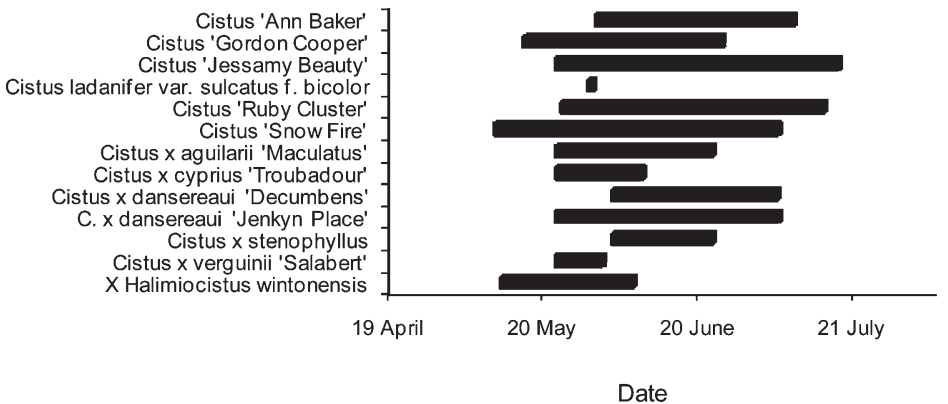

Fig. 1. Average flowering time and duration of blotched, white-flowered rockrose grown in a landscape evaluation at Aurora, OR, in 2005-06. Plants were considered in bloom when several open flowers were distributed through the shrub.

species and cultivars, the flowering characteristics of these plants were diverse. The effective flowering period for the three genera is late April to late July (Figs. 1-4). The earliest plant to bloom was Halimium calycinum, particularly the accession from California, which commenced blooming in the third week of April (Fig. 4), at about the same time as Halimium umbellatum ssp. umbellatum (Fig. $2)$. In the first week of May, other early-blooming cultivars such as $\mathrm{Cis}$ tus 'Grayswood Pink' and Cistus 'Bicolor Pink' began flowering (Fig. 3), followed by Cistus 'Snow Fire' and $\times$ Halimiocistus wintonensis (Fig. 1). The majority of flowering for these genera occurs from mid-May through the end of June. A few cultivars continue flowering quite strongly well into July, including $H$. xpananum and $H$. halimifolium forma maculatum (Fig. 4), Cistus inflatus (Fig. 2), Cistus Xpulperulentus 'Sunset' (Fig. 3), Cistus 'Ruby Cluster', and Cistus 'Jessamy Beauty' (Fig. 1).

The duration of the flowering period varied dramatically. The shortest bloom duration was that of C. ladanifer var. sulcatus forma bicolor, which flowered for only a few days (Fig. 1). A number of plants flowered for $10 \mathrm{~d}$ or less, including $C$. $\times$ verguinii, C. $\times$ argentens cultivars $\mathrm{Pa}-$ per Moon, Peggy Sammons, Blushing Peggy Sammons, and Stripey; C. salviifolius 'Gold Star', Cistus libanotis 'Major', C. ladanifer 'Blanche', C. $\times$ cyprius 'Elma', and Cistus $\times$ rodiae 


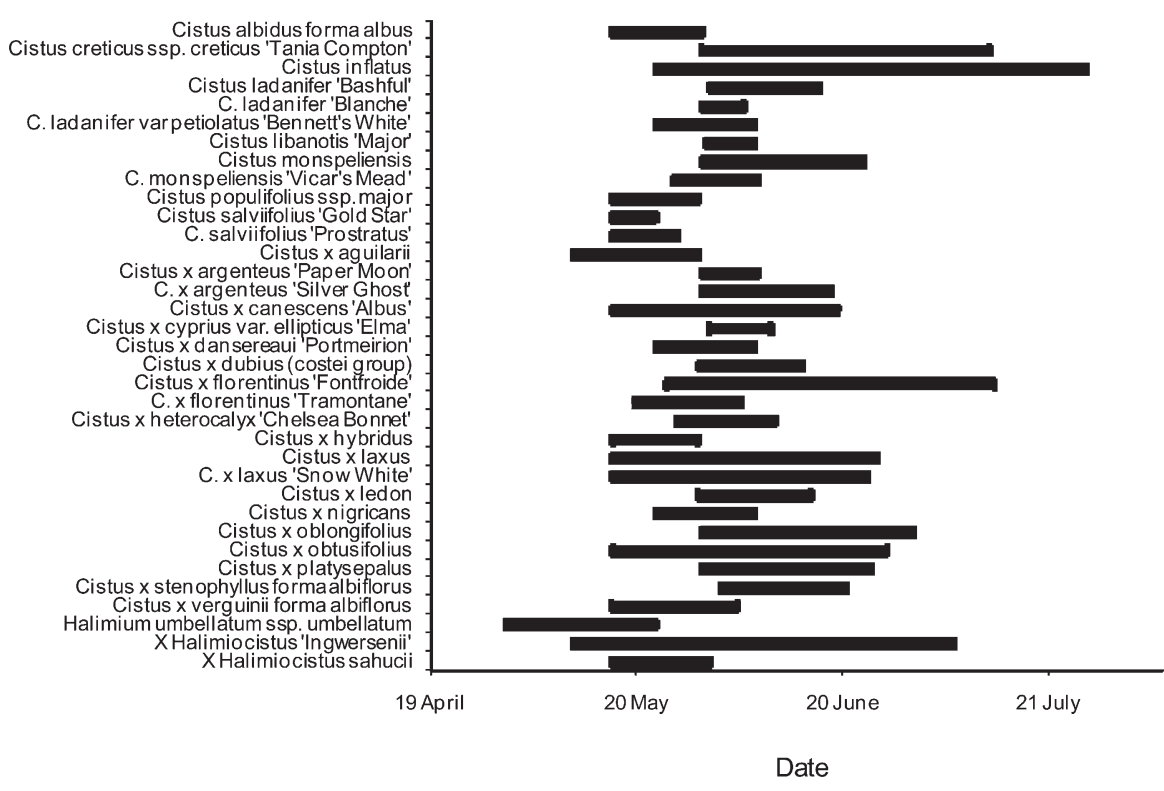

Fig. 2. Average flowering time and duration of white-flowered rockrose grown in a landscape evaluation at Aurora, OR, in 2005-06. Plants were considered in bloom when several open flowers were distributed through the shrub.

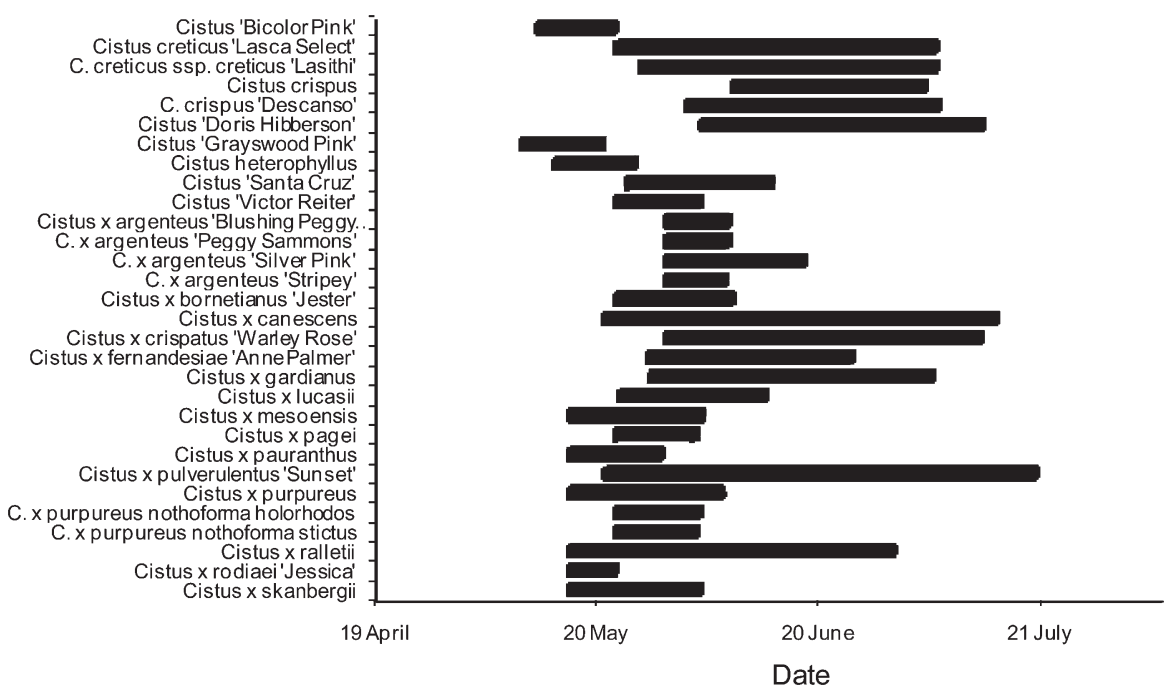

Fig. 3. Average flowering time and duration of pink-flowered rockrose grown in a landscape evaluation at Aurora, OR, in 2005-06. Plants were considered in bloom when several open flowers were distributed through the shrub.

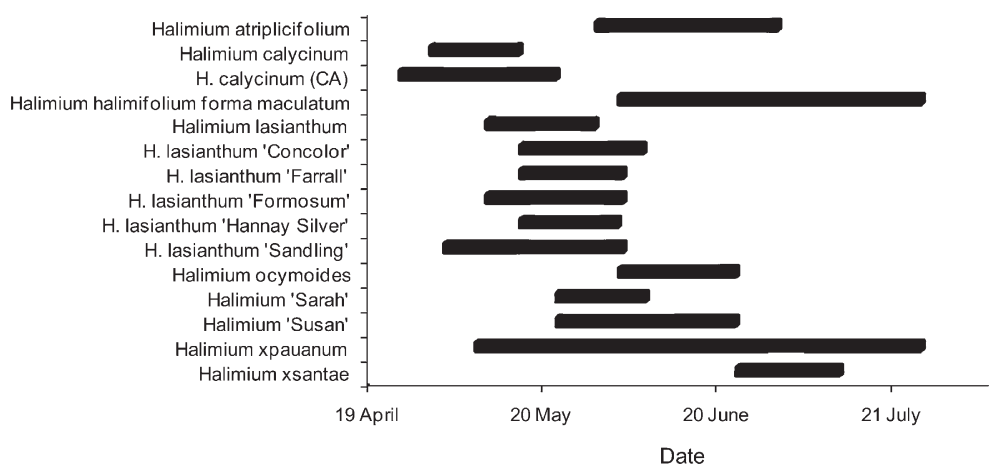

Fig. 4. Average flowering time and duration of yellow-flowered rockrose grown in a landscape evaluation at Aurora, OR, in 2005-06. Plants were considered in bloom when several open flowers were distributed through the shrub.
'Jessica'. The industry standards, $C$. $\times$ purpureus and $C$. $\times$ bybridus, flowered for 22 and $13 \mathrm{~d}$, respectively.

The longest bloom period belonged to $H$. ×pananum, which bloomed for $79 \mathrm{~d}$ (Fig. 4). A number of other plants bloomed in excess of $50 \mathrm{~d}$, including Cistus $\times$ canescens, C. ×pulverulentus 'Sunset', C. inflatus, C. ×florentinus 'Fontfroide', Cistus 'Jessamy Beauty', Cistus 'Ruby Cluster', Cistus 'Snow Fire', H. halimifolium forma maculatum, and $\times$ Halimiocistus 'Ingwersenii'. All of these can be counted on for a very long season of floral interest.

Differences in foliage quality, bloom time, and hardiness were readily evident throughout the evaluation. Some plants excelled in some areas but lacked considerably in others, thus their desirability is based on how important their particular strengths are. For example, C. salviifolius 'Gold Star' had excellent foliage ratings and would make a very good tall groundcover, but it has a very abbreviated bloom period. This is a similar problem with Cistus 'Grayswood Pink' and Cistus 'Bicolor Pink', which have attractive foliage and would make good small scale groundcovers, but exhibit bloom time of less than 2 weeks, short by the standards of this genus. Other plants, such as $H$. halimifolium forma maculatum, have very long bloom periods, but relative poor habit and foliage quality. And there were a few plants such as $H$. atriplicifolium and Cistus creticus 'Tania Compton' that have long bloom periods, but that are lacking in cold hardiness.

If foliage quality, length of bloom time, and hardiness are considered simultaneously, then a few of the plants evaluated are superior to the others. Many of these have a low, spreading or a mounding habit and would make good groundcovers for dry areas. Beginning with the most diminutive, these plants are C. ×gardianus, which forms a flat groundcover and features pink flowers. Of similar size is $C$. $\times$ pulverulentus 'Sunset', which is already well-known in the northwestern U.S. and is popular for its magenta flowers and long bloom period. C. ×obtusifolius forms a near-perfect dome of foliage and would make an excellent substitute for C. $\times$ bybridus, which is the standard white-flowering Cistus in the Pacific northwestern U.S. Unfortunately, C. Xbybridus is 
often massed as a groundcover in situations where it quickly outgrows its space, requiring repeated pruning to maintain its size. Most Cistus, including C. Xbybridus, do not tend to grow back from hard pruning. The flowering period for C. ×obtusifolius is nearly four times as long as for $C$. $\times$ bybridus, and it is considerably smaller in size. Similar in size to $C$. $\times$ obtusifolius is C. inflatus, which has a bloom period that approached 2 months, exceeded only by $H$. xpananum. Somewhat larger than C. inflatus is C. Xlaxus, which along with C. xobtusifolius, received the highest foliage rating of all plants in the evaluation. C. Xcanescens has soft gray leaves, pink flowers, and a tighter habit than $C$. $\times$ laxus, and also flowers for about 2 weeks longer. Larger than C. Xlaxus, and all of similar size, are Cistus 'Gordon Cooper', Cistus 'Snow Fire', and Cistus 'Ruby Cluster,' all of which form fairly large domes of foliage and which have blotched, white flowers. All of these had excellent foliage, bloomed for at least $40 \mathrm{~d}$ or longer, and would make excellent specimen plants or tall groundcovers.

Among the Halimium, $H$. lasianthum 'Sandling' distinguished itself as the best of the cultivars of the species. The average bloom time of H. lasianthum is $2 \mathrm{l} \mathrm{d}$, and 'Sandling' bloomed for 32. In addition, it had a foliage rating of 4.5 , superior to any other cultivar of that species (Table 1). Halimium 'Susan' received similarly high ratings for foliage and had a bloom period of 1 month, longer than most Halimium. Of those Halimium with an upright habit, the clear favorite was $H$. xpananum, which had a very long bloom time. Of the $\times$ Halimiocistus, the best was $\times$ Halimiocistus 'Ingwersenii', which featured good foliage and had an exceptionally long bloom period.

\section{Literature cited}

Acosta, A., M. Bellelli, S. Mazzoleni, C. Legg, and C. Blasi. 1997. Analysis of plant form in some Mediterranean shrubs. Plant Biosyst. 131:51-58.

Demoly, J.-P. 2006. Notes taxonomiques, chorologiques et nouveautés nomenclaturales pour le genre Cistus L. élargi, incluant Halimium (Dunal) Spach (Cistaceae). (Taxonomical, chorological and nomenclatural new data about the genus Cistus L., including Halimium (Dunal) Spach (Cistaceae)). Acta Bot. Gallica 153:309-323.

Garcia-Plazaola, J.I., A. Hernandez, and J.M. Becerril. 2000. Photoprotective responses to winter stress in evergreen Mediterranean ecosystems. Plant Biol. 2:530-535.

Johnson, A.T. 1947. Cistuses and frost. J. Royal Hort. Soc. 72:248-249.

Lonard, R.I. and F.W. Judd. 1991. Comparison of the effects of the severe freezes of 1983 and 1989 on native woody plants in the lower Rio Grande River Valley, Texas. Southwest. Nat. 36:213-217.

Mulligan, B.O. 1953. A Cistus collection in Seattle. J. California Hort. Soc. 14:131-141.

Mundie, A. 2001. Cistus trial 1997-2000. Northern Gardener 55:50-51.

Nahal, I. 1981. The Mediterranean climate from a biological viewpoint, p. $63-$ 86. In: F. Di Castri, D. Gooddall, and R. Specht (eds.). Mediterranean-type shrublands. Ecosystems of the world 11. Elsevier, Amsterdam, The Netherlands.

Nunez-Olivera, E., J. Martinez-Abaigar, and J.C. Escudero. 1994. Chlorophyll content of a Mediterranean shrub (Cistus ladanifer L.) over a latitude and altitude gradient in the Iberian Peninsula. Photosynthetica 30:133-042.

Oliveira, G. and J. Penuelas. 2004. Effects of winter cold stress on photosynthesis and photochemical efficiency of PSII of the Mediterranean Cistus albidus L. and Quercus ilex L. Plant Ecol. 175:179-191.

Page, R.G. 2009. The Cistus and Halimium website. 26 May 2009. <http:// www.cistuspage.org.uk/>.

Sanchez-Blanco, M.J., P. Rodriguez, M.A. Morales, M.F. Ortuno, and A. Torrecillas. 2002. Comparative growth and water relations of Cistus albidus and Cistus monspeliensis plants during water deficit conditions and recovery. Plant Sci. 162:107-113.

U.S. Bureau of Reclamation. 2009. Agrimet, The Pacific Northwest Cooperative Agriculture Weather Network. 29 May 2009. <http://www.usbr.gov/pn/ agrimet/webarcread.html>.

Varone, L. and L. Gratani. 2007. Physiological response of eight Mediterranean maquis species to low air temperatures during winter. Photosynthetica 45:385391.

Werner, C., O. Correia, and W. Beyschlag. 1999. Two different strategies of Mediterranean macchia plants to avoid photoinhibitory damage by excessive radiation levels during summer drought. Acta Oecol. 20:15-23.

Zunzunegui, M., M.C. Diaz Barradas, F. Ain-Lhout, A. Clavijo, and F. Garcia Novo. 2005. To live or to survive in Donana dunes: Adaptive responses of woody species under a Mediterranean climate. Plant Soil 273:77-89.

Zunzunegui, M., M.C. Diaz Barradas, F. Aguilar, F. Ain-Lhout, A. Clavijo, and F. Garcia Novo. 2002. Growth response of Halimium halimifolium at four sites with different soil water availability regimes in two contrasted hydrological cycles. Plant Soil 247:271-281. 